\title{
Perangkat Desa Melek Digital dan Kreatif: Pelatihan Pengembangan Konten Digital di Desa Ngijo Kabupaten Malang
}

\author{
Village Officer Who Digital Literated and Creative: Digital Content Development \\ Training in Desa Ngijo Kabupaten Malang
}

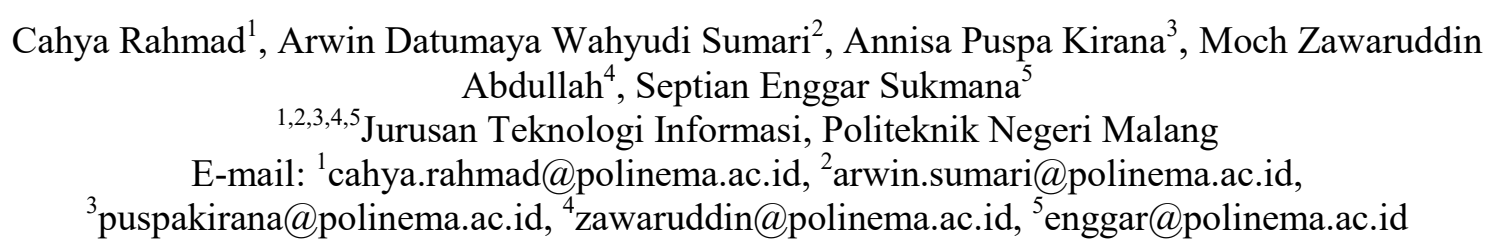

\begin{abstract}
Abstrak
Potensi pariwisata, kekayaan sumber daya pertanian, dan lokasi strategis Desa Ngijo, Kecamatan Karangploso, Kabupaten Malang perlu mendapatkan perhatian agar dapat terinformasikan kepada masyarakat luas. Desa Ngijo telah memiliki website sebagai media penyampaian informasi, namun sayangnya belum mampu menampilkan potensi dan sumbersumber daya tersebut dikarenakan keterbatasan kemampuan para perangkat desa untuk membangun konten-konten yang tepat. Untuk mengatasi permasalahan ini telah dilaksanakan pelatihan pengembangan konten digital agar para perangkat Desa Ngijo melek digital dan terpicu kreativitasnya untuk membangun konten-konten digital. Pada pelatihan ini digunakan perangkat desain grafis Canva yang dapat diperoleh secara gratis dari Internet. Canva memberikan keluwesan karena dapat dioperasikan melalui smartphone sehingga perangkat desa dapat memperbarui konten-konten website desanya setiap saat dibutuhkan. Berdasarkan hasil survei yang diberikan di akhir pelatihan, 90\% perangkat desa peserta pelatihan menyatakan bahwa pelatihan ini sangat bermanfaat dan menginginkan agar pelatihan seperti ini dilanjutkan.
\end{abstract}

Kata kunci: Desa Ngijo, konten digital, kreatif, melek digital, pelatihan, perangkat desa, website desa

\begin{abstract}
Tourism potential, wealth of agriculture resource, and strategic location of Desa Ngijo, Kecamatan Karangploso, Kabupaten Malang needs to have attention in order to be informed to the wider community. Desa Ngijo has already had a website as an information delivery medium, but unfortunately it is not capable of displaying such potential and resources because of the lack of village officers' capability to develop the proper contents. To cope with this problem, a digital content development training has been carried out in order that the Desa Ngijo's village officers are digital literated and triggered their creativity to develop digital contents. In this training, an-Internet-free-available Canva graphic design tool was used. Canva gives flexibility because it can be operated via smartphone so that the village officer can update his village website' contents anytime it is needed. Based on the survey results which was given at the end of the training, $90 \%$ of trainees village officer stated that the training is very useful and wanted that the training should be continued.
\end{abstract}

Keywords: creative, Desa Ngijo, digital content, digital literated, training, village officers, village website 


\section{PENDAHULUAN}

Perkembangan teknologi internet dan sistem informasi tumbuh semakin pesat dan canggih di seluruh belahan dunia [1]. Semakin banyak daerah yang sebelumnya sulit untuk diakses kini bisa dengan mudah dijangkau. Kemudahan akses dan pertumbuhan sistem informasi ini sendiri sudah selayaknya digunakan secara merata oleh seluruh perangkat pemerintah dan pelayanan ndust, dari tingkat kabupaten hingga desa. Kebutuhan akan sistem dan Teknologi Informasi menjadi sebuah tolak ukur dalam hal pengambilan keputusan dan kebijakan di sistem pelayanan [2][3]. Organisasi pemerintah yang berbasis kepada Teknologi Informasi menjadi hal yang sangat penting untuk menjamin kemudahan kelancaran proses komunikasi dan manajemen [6]. Komunikasi tidak akan berjalan tanpa bantuan sarana penyampai pesan atau media dalam hal ini adalah website [4][5].

Desa Ngijo adalah sebuah desa di wilayah Kecamatan Karangploso, Kabupaten Malang, Provinsi Jawa Timur dan terdiri atas 15 Rukun Warga (RW) dan Delapan Dusun antara lain: Dusun Kagrengan, Dusun Kedawung, Dusun Ngijo, Dusun Ngepeh, Dusun Takeran, Dusun Kendalsari, Dusun Leses, dan Dusun Perum GPA. Topografi ketinggian desa ini adalah berupa daratan sedang yaitu sekitar $525 \mathrm{~m}$ di atas permukaan air laut. Desa Ngijo adalah salah satu desa unggulan yang ada di Kabupaten Malang. Kantor Desa Ngijo merupakan instansi pemerintah yang bertugas memberikan pelayanan publik kepada masyarakat desa. Namun sayangnya di era informasi saat ini kantor desa belum mampu memiliki fasilitas yang memudahkan masyarakatnya untuk memperoleh informasi mengenai potensi dan sumber-sumber daya serta perkembangan pembangunan dan infrastruktur di desanya.

Agar masyarakat desa dan juga masyarakat yang lebih luas dapat memperoleh informasi dengan cepat dan mudah, maka Kantor Desa Ngijo sangat memerlukan sebuah sistem informasi berbasis web yang memuat profil tidak hanya Kantor namun juga masyarakat Desa Ngijo beserta beragam informasi yang dapat memperkenalkan semua potensi dan sumber daya kekayaan alam desa sehingga dapat berdampak pada peningkatan ekonomi masyarakat desa, di samping tugas utamanya untuk pelayanan publik. Berdasarkan pada hasil-hasil analisis situasi di atas, tim pengabdian kepada masyarakat Politeknik Negeri Malang (POLINEMA) menyelenggarakan kegiatan pelatihan pembangunan website profil Desa Ngijo bagi para perangkat desa khususnya perangkat desa yang bergerak di sub bagian Information Technology (IT). Tujuan dari pengabdian kepada masyarakat ini adalah mempermudah masyarakat untuk menerima informasi terbaru yang dapat diakses melalui internet dan membuat desain serta membangun website profil desa yang membantu masyarakat dalam mengakses informasi tentang perkembangan pembangunan dan infrastruktur desa.

Pelatihan yang diberikan kepada para perangkat desa ini diharapkan akan memberikan wawasan baru dalam pembangunan website profil desa dan menjadikan perangkat desa yang melek digital serta memicu kreativitas dalam pembangunan konten-konten digital. Desa yang memiliki Sistem Informasi yang baik akan mudah dalam memberikan informasi kepada masyarakat desanya dan juga kalangan yang lebih luas seperti Instansi-instansi Pemerintah terkait baik pada level daerah hingga pusat, dan masyarakat umum. Desa juga akan lebih mudah dikenal sehingga memudahkan dalam memperkenalkan dan mempromosikan potensi-potensi serta sumber-sumber kekayaan alam yang dimilikinya, seperti potensi ekonomi, potensi Sumber Daya Alam (SDA), potensi Sumber Daya Manusia (SDM), dan pariwisata yang berbasis budaya atau alam. Selain itu, akan mempermudah masyarakat dalam mengamati, dan mengakses informasi terbaru tentang data dan infrastruktur Desa Ngijo secara online. Dengan digunakannya Content Management System (CMS) dalam pembangunan website akan mempermudah dalam pemeliharaannya sehingga dapat kembangkan lagi untuk promosi potensipotensi industri maupun pariwisata di Desa Ngijo pada masa mendatang. 


\section{METODE PELAKSANAAN}

Kegiatan Program Pengabdian Kepada Masyarakat (PkM) POLINEMA ini dilaksakan di Kantor Desa Ngijo, Kabupaten Malang pada tanggal 23 Juli 2020 dan diikuti oleh 15 peserta perangkat desa. Sasaran Program PkM ini adalah tenaga administrasi khususnya tenaga IT dan Perangkat Desa di Kantor Desa Ngijo, Kabupaten Malang. Pelatihan dilaksanakan melalui beberapa tahapan awal, yaitu:

a. Perkenalan pada beberapa fitur yang telah ada pada website profil Kantor Desa Ngijo yang telah dikembangkan;

b. Pemberian pengetahuan tentang cara operasional dan proses administrasi pada website profil Kantor Desa Ngijo;

c. Pemberian beberapa contoh konten yang sebelumnya sudah diunggah;

d. Latihan secara mandiri dalam memperbarui dan mengelola website dengan bimbingan dari para pelaksana PkM.

Kegiatan PkM ini berupa implementasi komponen sistem informasi di Kantor Desa Ngijo, Kabupaten Malang dalam hal pengembangan konten. Agar kegiatan ini tepat guna serta dapat memberikan manfaat yang optimal maka baik pengusul kegiatan maupun mitra kegiatan harus merupakan pihak yang layak. Mitra kegiatan pengabdian ini adalah Kantor Desa Ngijo, Kabupaten Malang dengan pertimbangan bahwa Desa Ngijo belum memiliki website profil kantor Desa Ngijo. Selain itu, wilayah Desa Ngijo yang cukup luas menjadikan penggunaan sistem informasi berbasis web ini akan sangat membantu mempercepat aliran informasi ke masyarakat baik masyarakat Desa Ngijo maupun kalangan yang lebih luas.

Sebagai tim pelaksana kegiatan PkM ini adalah para dosen Jurusan Teknologi Informasi POLINEMA. Dari sisi pengusul, Jurusan Teknologi Informasi merupakan salah satu jurusan di POLINEMA dimana salah satu kompetensi utamanya adalah mendesain, membangun, dan mengimplementasikan sistem informasi. Kompetensi ini dibutuhkan untuk membantu Desa Ngijo membangun dan mengimplementasikan sistem informasi berbasis web di Kantor Desa Ngijo. Jurusan Teknologi Informasi memiliki SDM yang berkompeten untuk melaksanakan kegiatan ini. Dalam kegiatan PkM, pelaksanaan kegiatan ini dibimbing dan dipandu oleh tim dosen yang sesuai dengan bidangnya guna memberikan solusi yang tepat guna dan implementatif.

Tabel 1 Tim Pelaksana PkM Pelatihan Pengembangan Konten Digital

\begin{tabular}{|c|l|l|}
\hline No. & \multicolumn{1}{|c|}{ Nama Dosen } & \multicolumn{1}{|c|}{ Bidang Keahlian } \\
\hline 1 & Dr. Eng. Cahya Rahmad, ST., M. Kom & Information System \\
\hline 2 & $\begin{array}{l}\text { Kolonel Lek. Dr. Ir. Arwin Datumaya Wahyudi Sumari, } \\
\text { S.T., M.T., IPM, ASEAN Eng., ACPE }\end{array}$ & Information System \\
\hline 3 & Annisa Puspa Kirana, S. Kom, M. Kom & Information System \\
\hline 4 & Moch. Zawaruddin Abdullah, S.ST., M. Kom. & Information System \\
\hline 5 & Septian Enggar Sukmana, S.Pd., M. T & Multimedia \\
\hline
\end{tabular}

Dalam menyelesaikan permasalahan mitra masing-masing dosen dalam tim ini memiliki tugas dan tanggung jawab sesuai dengan bidang keahliannya sehingga saling melengkapi satu sama lain dan tercipta sinergi ilmu yang tepat dalam memberikan solusi atas permasalahan mitra. Sebagai tim yang solid beserta mahasiswa yang mendampingi, tim dosen PkM POLINEMA berusaha memberikan sumbangsih ilmu dan pikiran untuk masyarakat, khususnya kepada para perangkat desa di Kantor Desa Ngijo, guna menghasilkan pelatihan yang lebih 
kreatif dan menyenangkan peserta dan produk berupa website yang sesuai permintaan pihak mitra.

\section{HASIL DAN PEMBAHASAN}

Pada kegiatan pelatihan pengelolaan website dan pengabdian ini dilaksanakan selama satu hari, yang dibimbing oleh 2 (dua) orang narasumber, yang diikuti oleh Operator dan pegawai dari Kantor Desa Ngijo yang beralamat di Jl. Raya Ngijo No. 01, Kedawung, Ngijo, Kecamatan Karang Ploso, Kabupaten Malang, Provinsi Jawa Timur. Karena masih dalam masa pandemik Covid-19 semua kegiatan tetap dilakukan dengan mengikuti protokol Kesehatan. Panitia membagikan masker dan hand sanitizer gratis kepada peserta dan juga disediakan bilik disinfektan oleh Kantor Desa Ngijo. Selain itu panitia juga menerapkan pengaturan tempat duduk yang berjauhan antara satu peserta dengan peserta yang lain untuk menghindari penyebaran virus Covid -9. Sebelum praktek pembuatan konten interaktif website dan praktik penggunaan website yang telah dikembangkan oleh tim, pelatihan dibuka oleh Ketua Tim PkM, Dr. Eng. Cahya Rahmad, ST., M. Kom., dilanjutkan dengan sambutan oleh Kepala Desa Ngijo yaitu Bapak Mahdi Maulana.

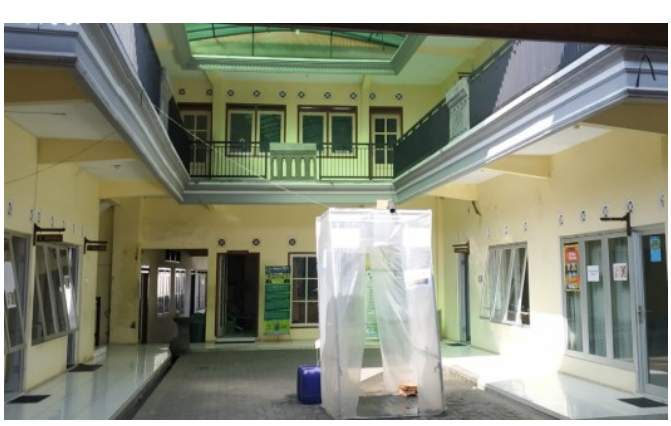

(a)

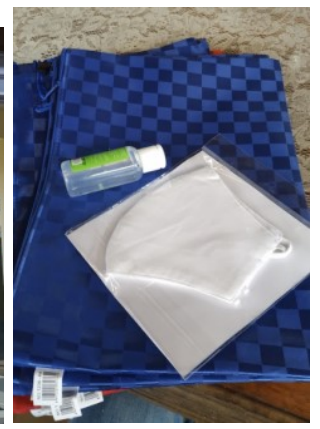

(b)

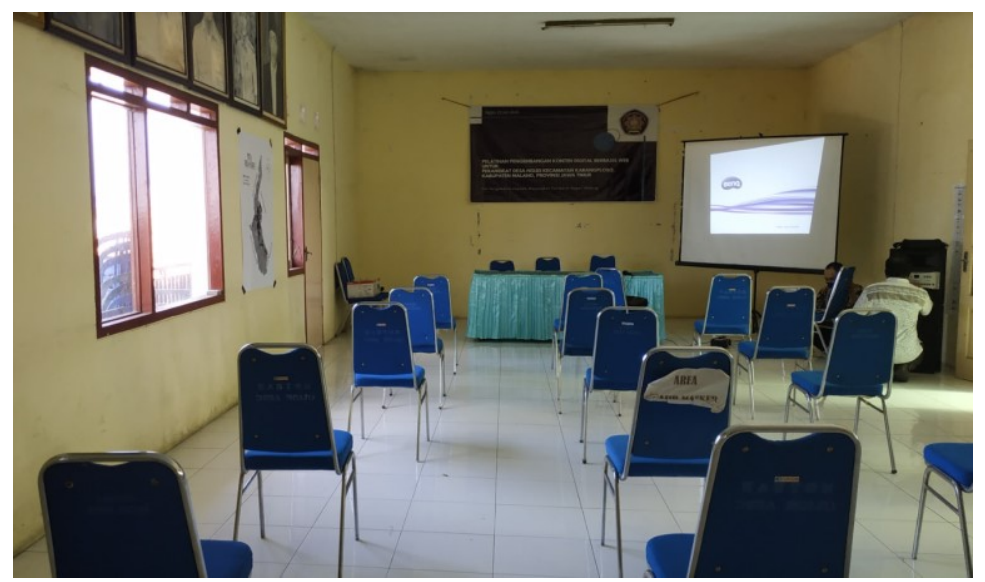

(c)

Gambar 1. Pengaturan protokol kesehatan di lokasi pelatihan: (a) bilik disinfektan; (b) masker dan hand sanitizer yang dibagikan ke peserta; (c) pengaturan tempat duduk

Kegiatan selanjutnya dilakukan diberikan pemaparan materi kepada perangkat desa tentang dasar-dasar Internet dan website dilanjutkan dengan pengetahuan singkat tentang aplikasi Canva. Aplikasi Canva ini yang nantinya akan digunakan untuk mengembangkan konten interaktif website maupun media sosial Kantor Desa Ngijo. Canva adalah sebuah perangkat (tools) yang dapat secara gratis di Internet untuk desain grafis yang menjembatani 
penggunanya agar dapat dengan mudah merancang berbagai jenis desain kreatif secara daring (online), mulai dari mendesain kartu ucapan, poster, brosur, info grafis, hingga presentasi. Canva saat tersedia dalam beberapa versi, web, iPhone, dan Android.

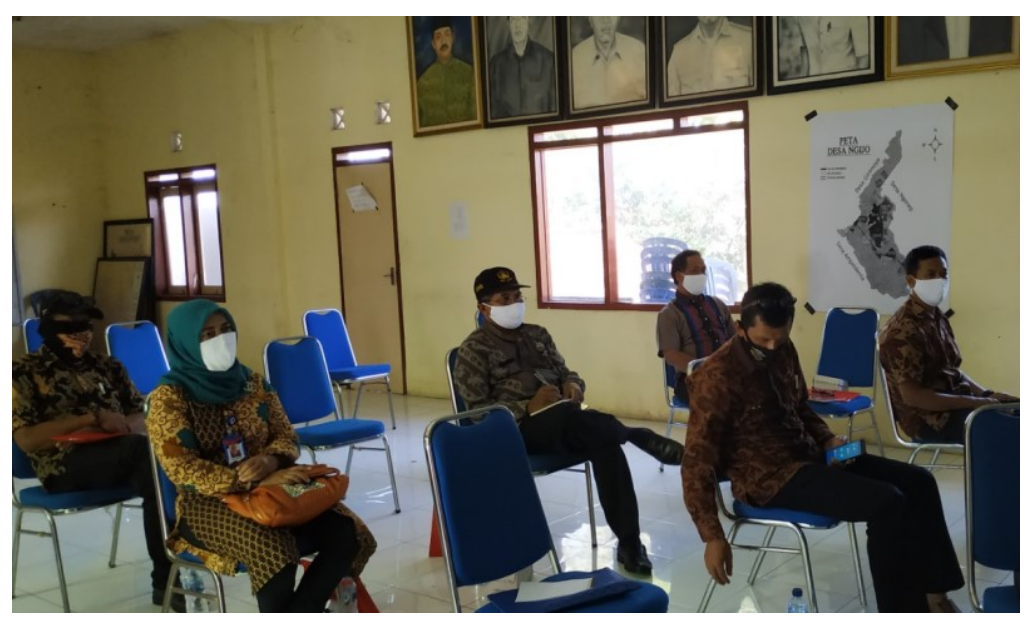

Gambar 2. Suasana peserta saat pelatihan

Kegiatan dilanjutkan dengan pengelolaan website dan pengisian konten digital. Peserta yang terdiri dari perangkat Desa khususnya yang menangani bidang IT. Peserta dilatih mempost-kan berita-berita kegiatan desa yang telah dilakukan, mengunggah foto-foto kegiatan desa, foto-foto kegiatan kantor Desa dan foto-foto lainnya. Peserta juga dilatih untuk menyesuaikan (cutomize) website, dengan mengunggah foto sampul web, dan mengatur menu-menu dan halaman-halaman pada website masing-masing.

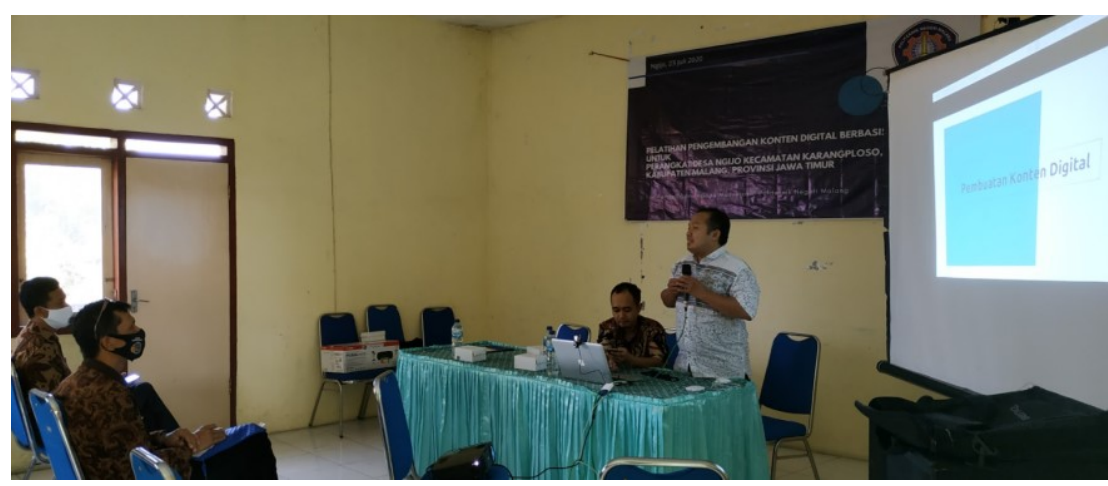

Gambar 3. Pemateri memberikan penjelasan tentang pengelolaan konten digital

Di akhir kegiatan, para peserta diminta untuk mengisi kuesioner terkait pelatihan pengembangan konten digital ini. Hasil-hasil dari penilaian peserta diperlihatkan pada Tabel 2. Berdasarkan analisis diperoleh informasi bahwa $90 \%$ peserta menilai bahwa pelatihan ini sangat bermanfaat pada penilaian tingkat kemanfaatan pelatihan, $100 \%$ menjawab materi pelatihan ini sangat mudah dipahami pada aspek kemudahan materi, dan $100 \%$ peserta menilai bahwa pelatihan ini perlu dilanjutkan.

Tabel 2 Hasil Penilaian Pelaksanaan Pelatihan oleh Perangkat Desa Ngijo

\begin{tabular}{|l|r|}
\hline Apakah pelatihan ini bermanfaat? \\
\hline sangat bermanfaat & 12 \\
\hline bermanfaat & 2 \\
\hline netral & 0 \\
\hline
\end{tabular}


Abdimasku, Vol. 4, No. 2, Januari 2021: 7-13

\begin{tabular}{|l|r|}
\hline kurang bermanfaat & 0 \\
\hline tidak bermanfaat & 0 \\
\hline Apakah materi pada pelatihan ini dapat dipahami? \\
\hline sangat mudah dipahami & 14 \\
\hline mudah dipahami & 0 \\
\hline sukar dipahami & 0 \\
\hline tidak dapat dipahami & 0 \\
\hline Apakah pelatihan ini perlu dilanjutkan? & 14 \\
\hline perlu dilanjutkan & 0 \\
\hline tidak perlu dilanjutkan & \\
\hline
\end{tabular}

\section{KESIMPULAN DAN SARAN}

Walaupun kondisi masih pada masa pandemi Covid-19, PkM POLINEMA dalam bentuk pelatihan pengembangan konten digital tetap dilaksanakan sesuai jadwal dengan tetap mematuhi protokol kesehatan. Pelatihan ini telah memberikan ilmu dan ketrampilan baru kepada para peserta pelatihan yaitu para perangkat Desa Ngijo yang didominasi oleh kelompok generasi Baby Boomer dan generasi X sehingga makin melek digital dan kreativitas digitalnya terbangun. Kegiatan ini juga dinilai bermanfaat oleh para peserta dan berharap dapat dilanjutkan melalui kegiatan-kegiatan yang bersifat asistensi (pendampingan). Bentuk-bentuk kegiatan yang dapat dilakukan untuk program pelatihan pada periode selanjutnya adalah: (1) sosialisasi dan pelatihan lanjut tentang penggunaan sistem informasi Profil Desa Ngijo khususnya pengembangan konten digital tersebut ke platform media sosial, dan (2) melakukan identifikasi kebutuhan sistem informasi Desa Ngijo yang akan diimplementasikan lebih lanjut berdasarkan skala prioritas.

\section{UCAPAN TERIMA KASIH}

Para penulis mengucapkan terima kasih kepada Direktur Politeknik Negeri Malang dan Kepala UPT P2M Politeknik Negeri Malang atas dukungan dana hibah Kompetisi Reguler sehingga PkM Pelatihan Pembangunan Konten Digital ini berjalan dengan baik dan lancar.

\section{DAFTAR PUSTAKA}

[1] Abdul Kadir. 2008. Tuntunan Praktis Belajar Database Menggunakan MySQL, C.V. Andi Offset. Yogyakarta

[2] Chandrakusuma Hardian. 2009. Perancangan Media Promosi Produk Teh Walini Organik PT. Perkebunan Nusantara VIII, Jurusan Desain Produk Industri, FTSP ITS.

[3] Gunawan, Wahyu., 2010, Kebut Sehari Jadi Web Master, Yogyakarta, Genius Publiser

[4] Indah Ika Nur, Yulianto Lies. 2013. Pembuatan Website Sebagai Sarana Promosi Produk Kelompok PIDRA Desa Gawang Kecamatan Kebonagung Kabupaten Pacitan, International Journal of Computer Science - Speed (IJCSS), 15 vol 10 no 1.

[5] Iqbal., 2009, Rekayasa Content Management System (CMS) Joomla Berbasis Open Source untuk Pengembangan Sistem Informasi Berbasis Online, Jurnal Informatika, Universitas Gajah Mada Yogyakarta, Vol 3, No.3 Januari. 
[6] Setiawan, Arifin.dkk., 2003, Menjadi Web Proggramer HTML, PHP, dan MySQL Dasar dan Aplikasi, www.id.or.id, diakses tanggal 23 Juli 2016. 